\title{
A DECADE OF ECONOMIC REFORMS IN INDIA: THE MINING SECTOR
}

\author{
Kanhaiya Singh*
}

Economics/RSPAS

The Australian National University, Canberra

\section{Kaliappa Kalirajan}

Foundation for the Advanced Studies on International Development

Tokyo

\footnotetext{
" The views expressed in this paper are authors' personal views and not that of the organizations they are associated with. This paper was a part of the consultancy for the forthcoming EAU (Economic Analytical Unit), DFAT report on India, entitled "India - New Economy, Old Economy". Comments and suggestions given by Frances Perkins, Michael Growder and another reviewer are acknowledged with thanks.
} 


\title{
A DECADE OF ECONOMIC REFORMS IN INDIA: THE MINING SECTOR
}

\author{
Kanhaiya Singh \\ Economics/RSPAS \\ The Australian National University, Canberra
}

\section{Kaliappa Kalirajan}

Foundation for the Advanced Studies on International Development

Tokyo

\section{INTRODUCTION}

The geological and metallurgical history of India is similar to mineral rich Australia, South Africa, South America, and Antarctica, all of which formed a continuous landmass before the breaking up of Gondwanaland. India contains minerals and resources. Some of them are known to be in abandon supply, while many are least known. At the current level of knowledge, India faces deficit in many minerals, particularly base metals and hydrocarbons. Considering the growing future needs and security of supply of these minerals, it has to enhance its resource base considerably through various options including intensive exploration drive, improving the recovery and production from the existing resource base and ensuring supplies through imports. India also needs to enhance its export potential of a number of minerals and metals, in which it has sufficiently large reserves.

The present thrust of deregulation is considerably driven from the fact that most of the mineral deposits, which are found on surface and easily extractable, have already been explored. Now, exploring agencies will have to look for increasingly difficult terrain and search mineral at greater depths with more sophisticated technology. This requires more capital and larger scale operations. In order to attract capital and technology from 
abroad the mining sector as a whole require adequate liberalisation. Considerable progress has been made in this direction in several areas. Yet many vital important areas are left behind. The aim of this paper is to review the progress made in liberalisation of the mining sector and flag important aspects that still need attention. A particular attention is paid towards the coal sector. Rest of the paper is organised as follows: Section 2 provides an overview of the mineral sector in India and its contribution to gross domestic product. Section 3 presents a brief legislative framework in which the industry has been operating. The review of reforms is presented in section 4 and conclusions are in section 5.

\section{AN OVERVIEW OF INDIA'S MINERAL SECTOR}

India produces 89 minerals including four fuel minerals, 52 non-metallic minerals, 11 metallic minerals and 22 minor minerals. Based on the 1996-97 production statistics, India stood as world's largest producer of mica blocks and mica splitting and ranked second in the production of chromites, third in coal \& lignite, and barytes, 5th in iron ore, 6th in bauxite and manganese ore, 11th in aluminium and 12th in crude steel in the World (IBM, 1999). Major deficiencies are experienced in the case of industrial minerals like petroleum, Copper, Lead, Zinc, Sulphur, Fluorspar, Kyanite and Rock phosphate. The demand in the case of most Ferro-alloys and several other minerals like Bauxite, Barytes, Chromites, Gypsum, Limestone, Manganese, Magnasite, Rutile, Silicon Minerals, Talc is fully met and there is surplus for exports. Steel grade coal is deficient in the country, while non-coking coal is abundantly produced.

The share of the mining and quarrying (M \& Q) sector in real gross domestic product (GDP) during 1993-94 was 2.57 percent with its contribution of 201 billion Rupees (Rs.) to the value addition, which grew to Rs. 252 billion rupees in 1998-99. However, the contribution to real GDP in 1998-99 was reduced to 2.33 percent (Figure 1). During this period $\mathrm{M} \& \mathrm{Q}$ sector has registered an average growth rate of about 3 percent in real terms, which is less than the growth rate of the economy as a whole. In terms of 
shares of value of minerals production by mineral groups, fuel minerals continue to dominate the total production with a share of more than 82 percent followed by distant metallic, minor, and non-metallic minerals respectively in the range of seven percent, six percent and four percent (see Figure 2) and, among the fuel minerals, coal, contributing more than half of the fuel production, still continues to play a dominant role among the domestic energy resources. Despite shifting of emphasis towards gas based power generation, coal is likely to remain the main energy resource due to its domestic availability in abundance and lower cost compared to other energy alternatives.

In terms of geographical distribution of mineral resources (see Figure 3), more than a quarter of mineral production come from the two states of Bihar $(\mathrm{BH})$ and Madhya Pradesh (MP) and slightly less than fifty percent of production originates from the ten states of Andhra Pradesh (AP), Assam (AS), Gujarat (GU), Maharastra (MH), Orissa (OR), Rajasthan (RJ), Tamilnadu (TN), Uttar Pradesh (UP), West Bengal (WB) and Karnataka (KT). ${ }^{1}$ One quarter of the value of production, mostly oil and gas comes from off shore. The states of Rajasthan, MP, Orissa, Karnatka, AP, Gujarat and Goa produce most of the metallic and non-metallic minerals, while majority of coal resources are confined in the regions covered by Bihar (now Jharkhand), West Bengal, Orissa, MP, Maharastra and AP.

With its contribution of about 16 percent in exports and 20 percent in imports, the mineral sector is an important component of India's foreign trade. However, this trade is not diversified. While the mineral exports is dominated by cut diamonds (77.58 percent during 1997-98), more than 80 percent of minerals imports is contributed by crude petroleum and uncut diamond. It is no secret that over the years India has emerged as

\footnotetext{
${ }^{1}$ The Union of India is divided in 35 states and union territories including the three newly constituted states of Uttarakhand, Jharkhand and Chhattisgarh by reorganizing erstwhile large states of Uttar Pradesh (UP), Bihar (BH) and Madhya Pradesh (MP) respectively in late 2000. For the purpose of this section, these three newly constituted states are considered as part of the original states because separate data for them is not yet available. Thus UP means UP and Uttarakhand, Bihar means Bihar and Jharkhand and MP means MP and Chhattisgarh. However, it is important to note that the new states have taken out most of the mineralised areas of the original states particularly in the case of Bihar and MP.
} 
one of the world's best and largest cutting and polishing centres for rough diamond but it is still deprived of the opportunities of processing larger size diamonds, probably because of the policies of the international diamond cartel, De Beer, and its common marketing agency, the central selling organization (CSO), which controlled the allocations of rough to cutting centres according to its own wish ${ }^{2}$. Smaller size roughs produced in Australia at Argyle find most of its way to Indian processors these days.

\section{KEY MINING POLICIES GOVERNING THE MINING INDUSTRY}

The Government of India introduced the New Industrial policy-1991 to bring out industrial de-regulation and to subsequently liberalize the provisions related to domestic and foreign investment. Since then the number of items requiring industrial licensing is reduced to a very minimum mostly confined to industries related to health and hazards and the list of industries reserved for the public sector is pruned drastically to a limited number of three items: (1) arms and ammunition and allied items of defence equipment, defence aircraft and warships; (2) Atomic energy; and (3) Railways.

From the liberalization measures mentioned above it would appear that domestic private and foreign investments are now possible in any feld of mining and quarrying sector including oil, petroleum, coal and minerals. However, it is misleading because there are multiple Acts in place to govern these sectors. In the case of petroleum and mineral oil, the legislative framework was simpler and therefore, private and foreign investments were possible immediately. However, in the case of coal, lignite and minerals, several other legislations are required to be amended in order to complete the reforms set out in the industrial policy. Therefore, in the following paragraphs such measures and their implications will be discussed in details. Nevertheless, the Indian Company law, the Labour law and the Factory Act are uniformly applicable to all sectors wherever applicable.

\footnotetext{
2 'Firms that cut and polish stones supplied by the CSO have no choice in what they buy; their purchases are allocated by De Beer' (Ghemawat and Patibandla (2000))
} 


\section{The general Legislative Framework for Mining other than Petroleum \& Gas}

The management of mineral resources in India is the responsibility of the Central Government and the State Governments as per the Constitution of India. The legislative framework governing the mining industry can be broadly represented as follows.

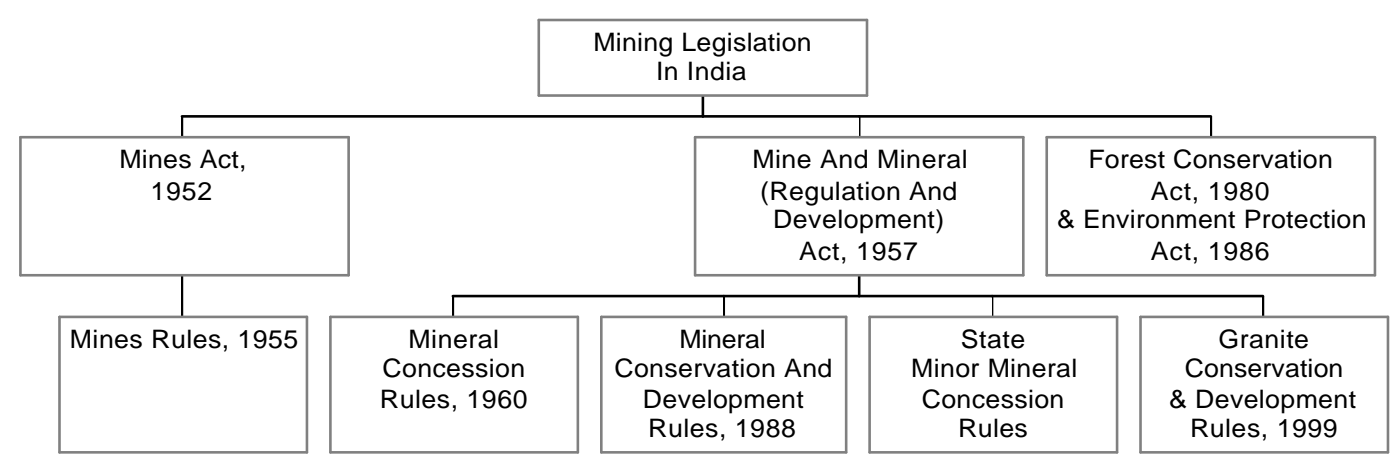

Source: Based on Gupta (1996)

The Mines and Minerals (Regulation and Development) Act, 1957 ('MMRD') lay down the legal framework for the regulation of mines and development of all minerals other than petroleum and natural gas. The health and safety of the workers is governed by Coal Mines Regulations 1957, Metalliferous Mines Regulations 1961, Maternity Benefits (Mines) Rules, 1963 and the Mines Rules, 1955 created under the jurisdiction of the Mines Act, 1952. Thus he Mines and Minerals (Development and Regulation Act, 1957, ('MMRD') and the Mines Act, 1952, together with the rules and regulations framed under them, constitute the basic laws governing the mining sector in India. The Director General of Mines Safety (DGMS) is responsible to enforce the provisions of the Mines Act.

Important rules in force under the MMDR Act are the Mineral Concession Rules, 1960, the Mineral Conservation and Development Rules, 1988 and Granite conservation \& development rules, 1999. The Mineral Concession Rules, 1960 outline the procedures and conditions for obtaining a Prospecting Licence or Mining Lease. The Mineral 
Conservation and Development Rules, 1988 lays down guidelines for ensuring mining on a scientific basis, while at the same time, conserving the environment. The minor minerals are separately notified and come under the purview of the State Governments. The State Governments have for this purpose formulated the Minor Mineral Concession Rules.

The provisions of Mineral Concession Rules and Mineral Conservation and Development Rules are, however, not applicable to coal, atomic minerals and minor minerals. In the case of coal mining, the operators have to comply with inspection and appropriate enforcement of conservation measures by the Coal Controller under the Coal Mines (Conservation and Development) Act, 1974 with a view to ensuring scientific mining.

The MMRD also provides regulations relating to prospecting fee, royalties, and dead rent in respect of the prospecting and mining leases for minerals other than minor minerals, payable to the State Government. The holder of the prospecting licence is required to pay annually, in advance. The holder of the Mining Lease for minerals other than minor minerals is liable to pay a Dead Rent to the State Government till any mineral is removed or consumed, from which time, the holder has to pay royalty or dead rent whichever is higher. These provisions of MMRD can only be amended by the Central Government through a notification in the official Gazette.

The royalty and the dead rent has been revised in order to make them more favourable to the private sector. The dead rent for the first year of the lease has been removed for all categories. The royalty rates and the dead rent for minor minerals are fixed by the respective State Governments. There are also cess and other taxes on minerals levied in accordance to the Cess \& Other taxes on Minerals (Validation) Act, 1992, which is applicable in respect of certain specific states like AP, Bihar, MP, Maharstra, Orissa, and Tamil Nadu to validate the imposition and collection of cesses and certain other taxes on minerals in those States.

All mining activities have to comply with the environmental legislation of India. The relevant acts in respect of environment protection forest (conservation) act 1980 and environment protection act and rules 1986. The forest (conservation) rules, 1981 
(amended up to may 1992) and the environmental impact assessment notification, 1994 also apply for all the mining projects.

It is the responsibility of the state administration to acquire land and then lease it to the mining operators. However, Coal being a mineral listed in the first Schedule of the MMRD Act, 1957, the State Governments can grant coal-mining leases only with the previous approval of the central Government accorded under the provision to Section 5 (1) of MMRD Act. Before the previous approval of the Central Government is accorded, the coal mining company is required to get the mining plan for the proposed coal mining area approved from the central Government. Acquiring land involves several agencies under the Land acquisition Act 1894, Coal Bearing Area (CBA) Act 1957 and the Forest Conservation Act 1980.

The coal mining leases under the MMRD Act are now granted for 20-30 years and can be renewed for a further period of 20 years with the previous approval of the central Government. The coal mining leases under the MMRD Act, 1957 are ordinarily subject to the ceiling of 10 square $\mathrm{km}$ of area.

\section{REFORMS INITIATED IN THE MINING SECTOR}

\section{Mineral sector (non-fuel, non-atomic)}

The 'New National Mineral Policy 1993' and subsequent reviews undertaken in 1994, 1997, 1999 and 2000 facilitate both the private and foreign participation in mineral industry and empower State Governments in decision making without permission prom the Central Government. The Mines and Minerals (Regulation \& Development) Act, 1957 has also been amended to incorporate such provisions. The Minerals (excepts fuel minerals and atomic minerals) which require prior concurrence of the Central Government for the grant of mineral concessions are reduced to 10 that include Asbestos, Bauxite, Zinc, Chrome Ore, Precious Stones, Copper Ore, Manganese Ore, 
Gold, Lead, and Iron Ore. In respect of all other non-fuel, non-atomic minerals State Governments can give permission of their own.

The concept of reconnaissance operations as a stage of operations distinct from and prior to actual prospecting operations has been introduced. However, the Reconnaissance Permit (RP) holder will have preferential right for grant of Prospecting License (PL). Earlier, the area restriction used to be for the all India but now the area limits for Reconnaissance Permits, Prospecting Licenses and Mining Leases will apply state wise. The maximum limit for RP for any company in a state is increased to 10,000 sq. $\mathrm{km}$ with each licence limited to $5000 \mathrm{sq}$. $\mathrm{km}$ maximum and it is given for a period of three years with a scheduled voluntary relinquishing plan without provision of any renewal. The maximum limit for PL for any company in a state is increased to $25 \mathrm{sq} . \mathrm{km}$ and it is given for a period of three years with a provision of renewal for two years. The maximum limit for Mining Lease (ML) for any company in a state is $10 \mathrm{sq} . \mathrm{km}$ and it is given for a period of 20-30 years with a provision of renewals in blocks of 20 years.

No case of renewal of prospecting license/ mining lease even for the 10 minerals listed above need reference to the Central Government. Similarly, transfer of mining leases even for these 10 minerals do not require reference to the Central Government. The State Governments have been delegated powers to grant mineral concessions even for areas, which are not compact or contiguous. Similarly, State Governments have been empowered to permit amalgamation of two or more adjoining mining leases. For large mining operations with investment proposals exceeding Rs. 2 billion, mining lease shall not lapse if mining development does not take place within two years. Level playing field between Government owned Companies and others have been provided e.g. prematurely terminated lease area available for re-grant for both public and private sectors and Government owned companies can not charge premium in case of transfer of mining lease.

The FDI policy in the mining sector was further liberalised in January 1997 and February 2000, which have opened up an "automatic approval" route for specific investments 
involving foreign equity participation. There will be no difference in the caps on foreign equity holdings to be allowed at the stages of exploration and that of mining. For all minerals with which the Department of Mines is concerned other than diamonds \& precious stones, foreign equity holding up to 100 percent is allowed on the automatic route $^{3}$, for both exploration and mining. In the case of diamonds \& precious stones, foreign equity up to 74 percent is allowed on the automatic route for both exploration and mining operations. For proposals seeking higher than 74 percent foreign equity, the cases will have to come to FIPB for clearance. Foreign equity up to 100 percent will be allowed on the automatic route for processing of minerals and metallurgy. There will be no requirement of NOC from an existing joint venture partner for fresh investments. The prospective investor will only have to give a declaration that he has no existing joint venture for the same area and/ or the particular mineral.

\section{State Governments' involvement}

In India, in general, the Central Government frames the legislation, while the State Governments make laws to implement them. However, as noted above the role of State governments has substantially increased in the management of the mineral sector. With liberalisation and development of competitive attitudes among the States, the State Governments are supplementing the lead of the Central Government by formulating and adopting policies that facilitate foreign and private investments. The rules are in place and the states have been given substantial freehand. The differences lie in the marketing efforts of the States. The leading role has been played by the state of Rajasthan, which is endowed with a variety of metallic, non-metallic and minor minerals, and has large number of private sector mining operators.

\footnotetext{
${ }^{3}$ The main route of foreign investment in India is through Government Approvals known as Foreign Investment Promotion Board (FIPB)/ Secretariat of Investment Approvals (SIA) route. SIA is part of department of Industrial Policy \& Promotion. However, for facilitating the FDI there is provision of Reserve Bank of India (RBI) Automatic Approvals under the delegated power of the government of India. The investment limits for automatic approvals for various Industrial activities under this scheme are notified by the department of Industrial Policy \& Promotion, Ministry of Industry. The administrative departments of the respective industries then make changes in the procedures.
} 
The detailed 'Mineral Policy 2000 '4 of Rajasthan is first of its kind, introduced in any State. Its focus is on clarity of procedures, transparency and accountability. The positive effects of this policy were reflected by offers of some of the early mineral concessions to foreign investment companies like BHP Minerals (India), CRA Exploration (India), Metmin Finance and Holding Limited, and Phelps Dodge Exploration India Pvt. Ltd in this state. Some of these and other foreign companies like Geomysore Services India Pvt. Ltd are now offered large area Mineral Concessions (RP) in AP, KT, GU, MH, $\mathrm{UP}, \mathrm{OR}$, and TN, which are also in forefront of marketing efforts. Recently the state of Karnataka has also formulated the Mineral Policy. Other states, with substantial business in minerals have set up directorates for speedy clearance of mining lease and land and follow up with the Central Government. AP and MP have specific plans for developing Granite and Diamond parks respectively. Orissa is also trying to follow the Rajasthan model. Andhra Pradesh is developing a high tech administration. Some of the Progress/developments regarding investment are on line to add transparency. With the division of Bihar, mineral rich part of the State has been converted into the new state of Jharkhand, which will have to work a lot to come out of its Bihar image of social unrest, and FDI unfriendliness.

\section{Achievements}

During the period of 1992-2000, 67 approval with a foreign equity participation of about Rs 37 billion have been granted, out of which nine were approved during 2000, seven during 1999, 13 during 1998, 6 during 1997, 24 during 1996, four during 1995, two during 1994 and one each during 1993 and 1992. More than 90,000 square km area in the states of Rajasthan, Gujarat, Maharashtra, Uttar Pradesh, Bihar, Haryana and Madhya Pradesh have been cleared in pursuance of the guidelines issued by the department of mines in October 1996. The reconnaissance/prospecting licenses have been granted to Indian subsidiaries of the well known international mining companies 4 The 'Mineral Policy 2000' of Rajasthan can be down loaded from
http://www.rajgovt.org/mineral.htm 
including the CRA Exploration India Pvt. Ltd., Metmin Finance and Holding Ltd., BHP Minerals India Pvt. Ltd., Meridian Minerals India Pvt. Ltd., RBW Minerals Industries Ltd., WSIL Minerals Sands India Pvt. Ltd., Phelps Dodge Exploration India Pvt. Ltd., besides public sector company, Hindustan Zinc Limited (Ministry of Mines Annual Report 1999-2000).

The efforts made so far in deregulating and creating provisions for easy FDI are commendable. The entire taxation regime applicable to the mineral sector is under review and it is expected to be made more investment friendly. Similar efforts are needed in the area of rationalisation of tariffs on the imported technology and capital goods for investment projects. However, it a complex issue and several considerations are involved. Therefore, drastic changes cannot be expected. The reform is an on-going process and improvements are needed as the system moves forward. However, equally important is the way the new agenda is implemented. The roles of the State Governments have become critical to their success. Procedural transparency in distribution of licence/lease, environment clearances, exit-policies, and incentives can be improved through meticulous documentation and creation of checklists. Design of the state Level policies, the application forms and elimination of the element of subjectivity, should be the thrust of next phase. Often, is the case that the objection and the replies come in instalments due to lack of clarity about the needed information.

\section{Coal and lignite sector}

The most important legislative enactment in the history of the coal sector in India is due to the Coal Mines (Nationalisation) Act 1973, which brought the coal sector firmly under the command of the public sector. Because of this, it can be argued that coal and lignite are still under a strictly controlled regime. Nevertheless, with the 1993 amendments in the Coal Mines (Nationalisation) Act (1973), the current legal framework has vested sufficient power with the Central Government to selectively allow coal mining for captive consumption of any industries through notifications. Thus far, the captive coal mining is allowed for the production of iron and steel, power, cement, and washing of coal. A 
captive coal block is not allowed to sell its produce in the open market and all of that must go to the end-use industry for which it is approved. Special dispensations are provided for setting up of associated coal companies by the end-user parties. A Company engaged in any of the approved end-use can mine coal from a captive block through an associated company formed with the sole objective of mining coal and supplying the coal on exclusive basis from the captive coal block to the end-user company, provided the end-user company has at least 26 percent equity ownership in the associated coal company at all times. Further, there can be a holding company with two subsidiaries i.e. (i) a company engaged in any of the approved end-uses and (ii) an associated company formed with the sole objective of mining coal and supplying the coal on exclusive basis from the captive coal block to the end-user company, provided the end-user company has at least 26 percent equity ownership in both the end-user company and the associated coal company.

Private Indian Companies setting up or operating power projects as well as coal or lignite mines for captive consumption are allowed FDI up to 100 percent. 100 Percent FDI is also allowed for setting up coal processing plants subject to the condition that the company shall not do coal mining and shall not sell washed coal or sized coal from its coal processing plants in the open market and shall supply the washed or sized coal to those parties who are supplying raw coal to coal processing plants for washing or sizing. FDI up to 74 percent is allowed for exploration or mining of coal or lignite for captive consumption. In all the above cases, FDI is allowed up to 50 percent under the automatic route subject to the condition that such investment shall not exceed 49 percent of the equity of a PSU. This means that FDI is not permitted for captive coal mining for washeries, steel plant and cement industry.

Another important step forward in the area of liberalisation of the coal sector is the decontrol of administered pricing regime. Prior to 1.1.2000, the Central Government was empowered under section 4 of the Colliery Control Order, 1945, and under the essential Commodities Act, 1955, to fix the grade-wise and colliery-wise prices of coal. Following the recommendations of the Bureau of Industrial Costs and Prices (BICP), the coal 
prices have been decontrolled in phases. Full deregulation was put in place after the Colliery Control Order, 2000 was notified with effect from $1^{\text {st }}$ January 2000 in suspension of the Colliery Control Order, 1945 (Annual Report, Ministry of Coal 20002001). Much before implementation of full decontrol of coal prices, tariff on coal import was brought down to the minimum level as it was felt that the domestic industry had no threat from imports what so ever.

\section{Achievements in Coal and lignite sector}

As discussed earlier, coal is yet to be opened beyond captive mining. At present according to the Annual Report of the Ministry of Coal (1999-2000), one hundred and five Captive Mining Blocks in the command area of CIL with an estimated reserve of 27563 million tones have been identified for Captive Mining. As on 6.3.2000, twenty-six firms in public and private sectors have been offered captive coal blocks for consumption in power generation, Iron \& Steel industry and cement industry.

\section{Need for Further Reforms in the coal Sector}

The need for reforms in the coal sector, particularly participation of the private sector can be linked through the economic growth. Electricity consumption per capita is one of the vital indicators of development. Besides, its direct role in the production process, it is also a need of every day life. During 1998, electricity consumption in India in terms of kilowatt-hour per capita (KWH-PC) was just 348 compared to 746 in China and 8717 in Australia (see Table 1). At the same time the per capita income in 1998 at 1995 US\$ was $\$ 430, \$ 725$ and $\$ 22821$, respectively (see Table 2). However, there is one common aspect in all these three countries, which is the share of the coal based electricity generation. The shares of the coal based electricity production in India, China and Australia were 75, 76 and 80 percent respectively (see Table 1). This has happened because coal based energy for these countries is cheap, cost effective and domestically available. In 1990, the shares of coal in these countries were 68, 73 and 77 percent respectively. The possibility of reversal of this trend in near future is remote. Therefore, it 
can be argued that if India's energy consumption has to improve, the major contribution must come from the coal sector.

During 1998-99, the recorded production of coal was 293 million tonnes, which increased to 323 million tonnes in 2000-01 (estimated), achieving an annual growth rate of 4.9 percent. This would amount to about 3 percent growth in terms of per capita. Thus, if India has to reach the energy consumption level that of China, it would take another 25 years if it has to rely on one monolithic coal producer. The private sector contribution in coal production is only of the order of 2 percent.

The Indian leadership has ambitious plan of much faster economic growth rate. As mentioned above, it is not only the production of goods that requires electricity, but also the consumption of goods. Therefore, unless the economy is fully developed, the electricity demand is likely to grow at a faster rate than the economic growth. Consider for example the case of the United States of America and the United Kingdom. During 1960-1980 the per capita real GDP in these countries grew at an average rate of about 2.3 and 2.0 percent, respectively but their per capita electricity consumption grew at the rate of about 4.3 and 3.4 percent, respectively during the same period (see Table 2). However, during the period of 1980-98, the per capita electricity consumption has grown at the rate of about 1.6 and 1.4 percent, respectively while economic growth remained almost similar. In the case of India during 1980-98, the per capita real GDP has grown at an average rate of about 3.5 percent, while the per capita electricity consumption has grown at the rate of 6 percent. However, it appears that China has been able to maintain a higher economic growth with less power intensity, where the per capita real GDP has grown at an average rate of about 8.0 percent, while the per capita electricity consumption has grown at the rate of 5.8 percent during 1980-98.

Therefore, if India aims at a per capita growth rate of 5 percent it may be reasonable to guess the electricity demand to grow at about 8 percent, which is more than double the rate at which coal production is growing at the moment. Economic growth without electricity growth in a democratic society may lead to chaos and political as well as social 
instability. Coal demand would increase several folds within 10-20 years. Coal development is a backward linkage to the completion of on-going coal base power projects and new projects envisaged in the areas of coal-based power, and metallurgical and other industries. Coal India Limited (CIL) and its subsidiaries would not be able to meet that demand and sooner this sector is fully opened for private participation at a large scale better would it be. It may be noted that coal development projects have very long gestation period and are highly capital intensive. Therefore, participation of largescale operators is a precondition for a substantial change.

Besides, India lacks reserves of good quality coking coal compared to the reserves of non-coking coal and Low Volatile Medium coking coals (LMVC). However, innovative technologies can be applied to wash LMVC and low-ash non-coking coal to produce steel grade coals. This would reduce countries dependence on the imports of coking coal. Again private sector participation needs to be encouraged in this area. Private participation is also required in coking coal washing. However, all this adds up to the urgent requirement of the presence of large-scale private sector including international companies in all areas of coal development.

The dismantling of the administered price regime in the coal sector is complete. When decontrol was proposed, some experts felt that full decontrol of coal pricing may lead unjustifiably high spurt in coal prices, which the public sector company may resort to in order to increase profitability without concern of improvements in productivity. Therefore, partly due to this reason and partly in order to bring early competitive equilibrium in coal production, it was recommended to break the monopolistic coal company into several competing public sector companies, which may later be put into the process of privatisation. As the implementation of the full decontrol of coal price has not resulted in any unprecedented price rise, it can be argued that the coal companies may be following the formula that has been prevailing during the administered regime.

However, both bringing the private sector at a large scale into coal sector and breaking the monolithic public sector coal company, require substantial political will and consensus 
among different parties. There can be several reasons for resistance. One is the sentiment attached with CIL, which has gone a long way in developing the coal sector in India on a massive scale. It runs about 500 mines and several attached institutions engaged in technological developments and planning and virtually it alone justifies, the existence of the Ministry of Coal, the power centre. Second resistance comes from the concerns of resource conservation and optimal exploitation. It is feared that the private companies may not be responsible for optimally exploiting the resources, reclaiming the land after use, and most of the low-grade coal might be left unexploited forever. However, such fear is also a reflection of weakness in the institutional developments and implementing the mechanisms already in place. For example there is no statutory regulation to force the mining company reclaim land to pre-use condition. Huge environmental backlogs are reported in several studies on the coal sector. Institutions responsible for implementing the existing environmental regulations, deforestation, land use plans, mining methods and safety of personal already exist. Any further externality of the mining industry, which cannot be left to the market forces, can be dealt with through appropriate regulatory system.

Even in the limited liberalisation of the coal mining discussed earlier, there is at least one major problem associated with the present system of identification and distribution of the captive coal blocks. Coal India limited and Andhra Pradesh owned Singareni Collieries Company (SCCL) have the entire coal block under their de-facto control. Both are instrumental in identification and the distribution of coal blocks to the private sector. Blocks already identified for development by $\mathrm{CIL}$ and blocks in the area where CIL has made investment for developing infrastructure are not to be offered to the private sector. Further the public/private sectors are required to bear the full cost of exploration in blocks on offer. Although, at the surface these guidelines seem to be legitimate, they erode the freedom of choice of the captive miners and give enough space to CIL and SCCL to have their way. In this context, besides legislative changes, reorganization of the coal sector and its control needs to be put in place to improve the transparency in information dissemination and distribution of the blocks. 
The approach paper to the tenth five year plan (2002-2007) prepared by the Planning Commission of India notes that if electric power is to expand to support the envisaged growth rate, a substantial expansion in domestic coal production will be needed. It is the only sector that is not open to private investment. There are two main stumbling blocks in allowing full participation of the private sector in coal. First, it is the existence of the coalmines (Nationalisation) Act 1973 as mentioned earlier. The second is the potential problem that is envisaged due to the 'Samatha Judgement', which put restriction on private coal mining in the tribal areas. Both these problems need to be addressed by the legislative amendments. A proposal for amending the Coal Mines (Nationalisation) Act 1973 has been introduced in the Parliament. However, it is yet to see its passage.

Full deregulation of the coal sector will boost domestic and foreign private sector participation in other mineral sector as well. Several international companies look for substantial business in countries of their operations. Opening up of the coal sector will attract such sitting ducks. It is evident from the above discussion that bringing full deregulation in to the coal sector requires a lot of homework and it will consume time. Therefore, process must begin now. It is already too late.

\section{CONCLUSIONS}

Considering the growing future needs and security of the supply of minerals, India has to enhance its resource base considerably through various options including intensive exploration drive, improving the recovery and production from the existing resource base and ensuring supplies through imports. India also needs to enhance its export potential of a number of minerals and metals, in which it has sufficiently large reserves. The present thrust of deregulation is considerably driven from the fact that most of the future exploration has to be done in increasingly difficult terrain and greater depths with more sophisticated technology. Domestic and foreign private sector participation may be lot helpful in this regard.

In order to attract capital and technology from abroad, the mineral, sectors except coal are adequately liberalised and provisions of FDI are made simple. The State 
Governments are engaged in supplementing the efforts of the Central Government. Several international companies from North America and Europe have recognised the existence of opportunities of business in India.

However, without opening up the coal sector for large-scale operations, liberalisation of the mineral sector will remain incomplete and until then the full benefits will not be harnessed. The analysis indicates that it is only a matter of time; the coal sector will have to be opened fully. So, why not sooner, which will be better.

\section{REFERENCES}

Ghemawat, P. and Patibandla, M., 'India's Exports since the Reforms Three Analytic Industry Studies' in Jeffrey D. Sachs, Ashutosh Varshney and Nirupam Bajpai (eds) India in the Era of Economic Reforms, New Delhi, Oxford University Press.

Government of India, 2000, 'Report of the Group on India Hydrocarbons Vision$2025^{\prime}$.

, 'Economic Survey', various issues.

Gupta, M.L., 1996, 'India's Mining Industry - Scope for Growth and Investment', Calcutta, the Mining, Geological \& Metallurgical Institute of India.

Indian Bureau of Mines, 1999, 'Indian Minerals handbook 1998 and 1999', Nagpur, Indian Bureau of Mines Press, December.

Ministry of Coal, Government of India, 2000, ‘Annual report 1999-2000’.

Ministry of Coal, Government of India, 2001, 'Annual report 2000-2001'.

Ministry of Coal, Government of India, 'Eligibility to Coal Mining', http://www.nic.in/vscoal/eligibility_to_coal_mining.htm, accessed on 28 November 2000.

Ministry of Industry, Government of India, 2000 'Industrial Policy', http://www.nic.in/vsindmin/policy/policy/policy.htm, accessed on 13 March 2001.

Ministry of Mines, Government of India, 'India's Mineral Sector', http://www.nic.in/mines/imsector.html, accessed on 10 April 2001. 
Ministry of Mines, Government of India, 'Private Participation and Foreign Investment', http://www.nic.in/mines/ppfinvest.html, accessed on 10 April 2001.

Ministry of Mines, Government of India, 'National Mineral Policy, 1993', http://www.nic.in/mines/nmp.html, accessed on 10 April 2001.

Ministry of Mines, Government of India, 'Mining Legislations', http://www.nic.in/mines/rdgnrest.html, accessed on 10 April 2001.

Ministry of Mines, Government of India, 2000, 'Annual report 1999-2000'.

Ministry of Mines, Government of India, 2001, 'Annual report 2000-2001'.

Ministry of Petroleum and Natural Gas, Government of India, 2000 'Annual report 1999-2000'.

Planning Commission, Government of India, 2001, 'Approach Paper to the tenth five year plan (2002-2007)'

Reserve Bank of India, 2000, 'Handbook of Statistics on Indian Economy', Mumbai, Charan Singh for the Reserve Bank of India.

The Financial Express, Various issues. 
Figure 1

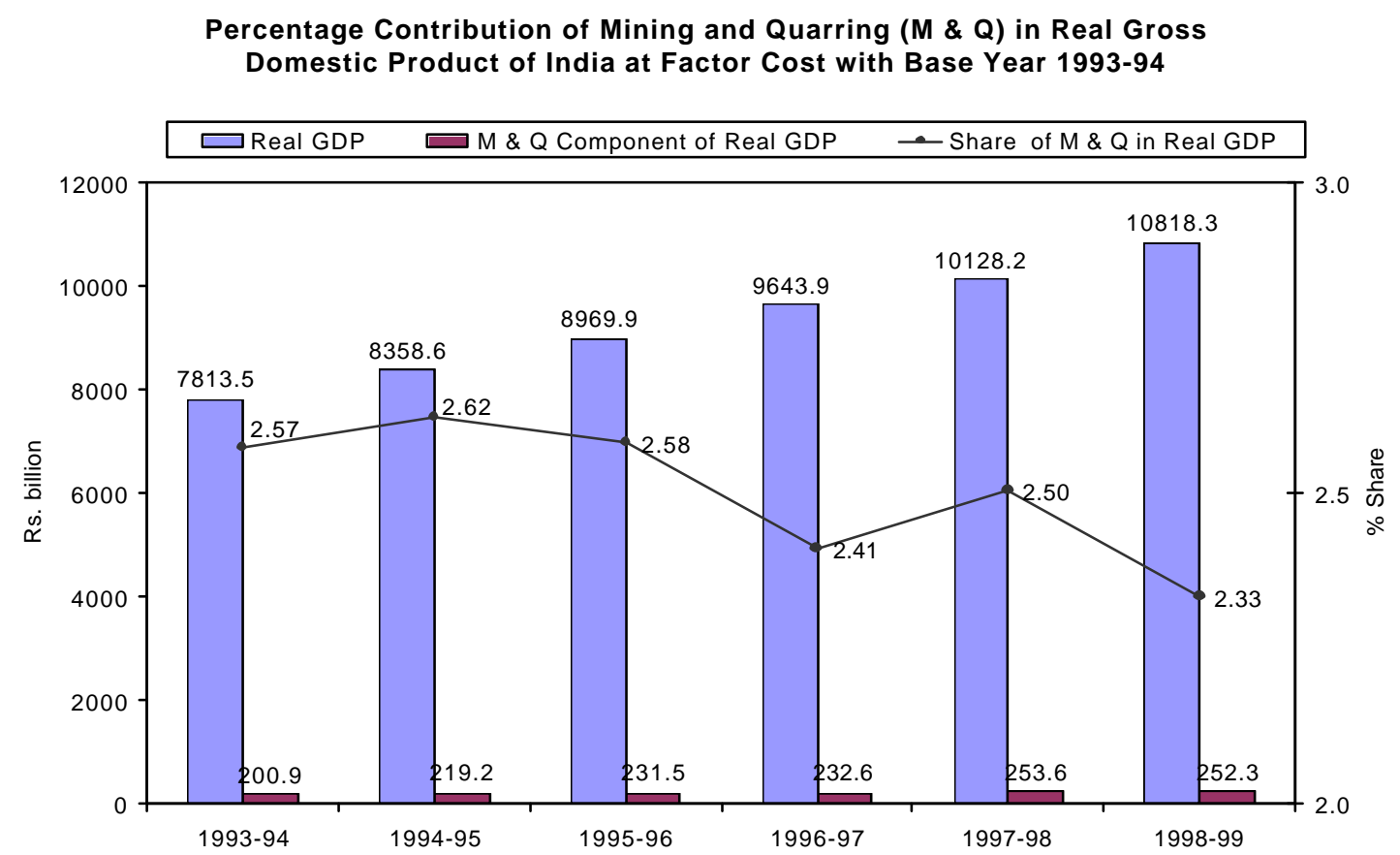

Source: Reserve Bank of India 2000

Distribution of Value of Mineral Production by Mineral Group 1998-99

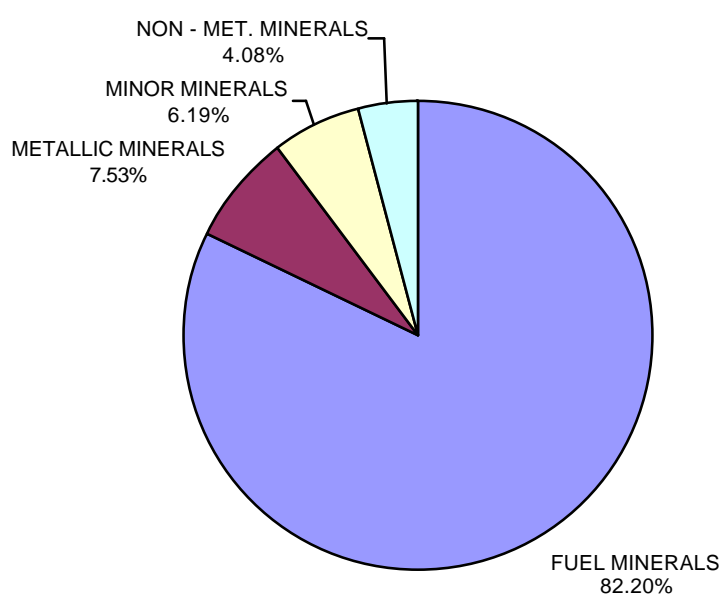

Figure 2 
Source: Indian Bureau of Mines 1998-99

Figure 3

Share of States in Production of Total Minerals by Value 1998-99

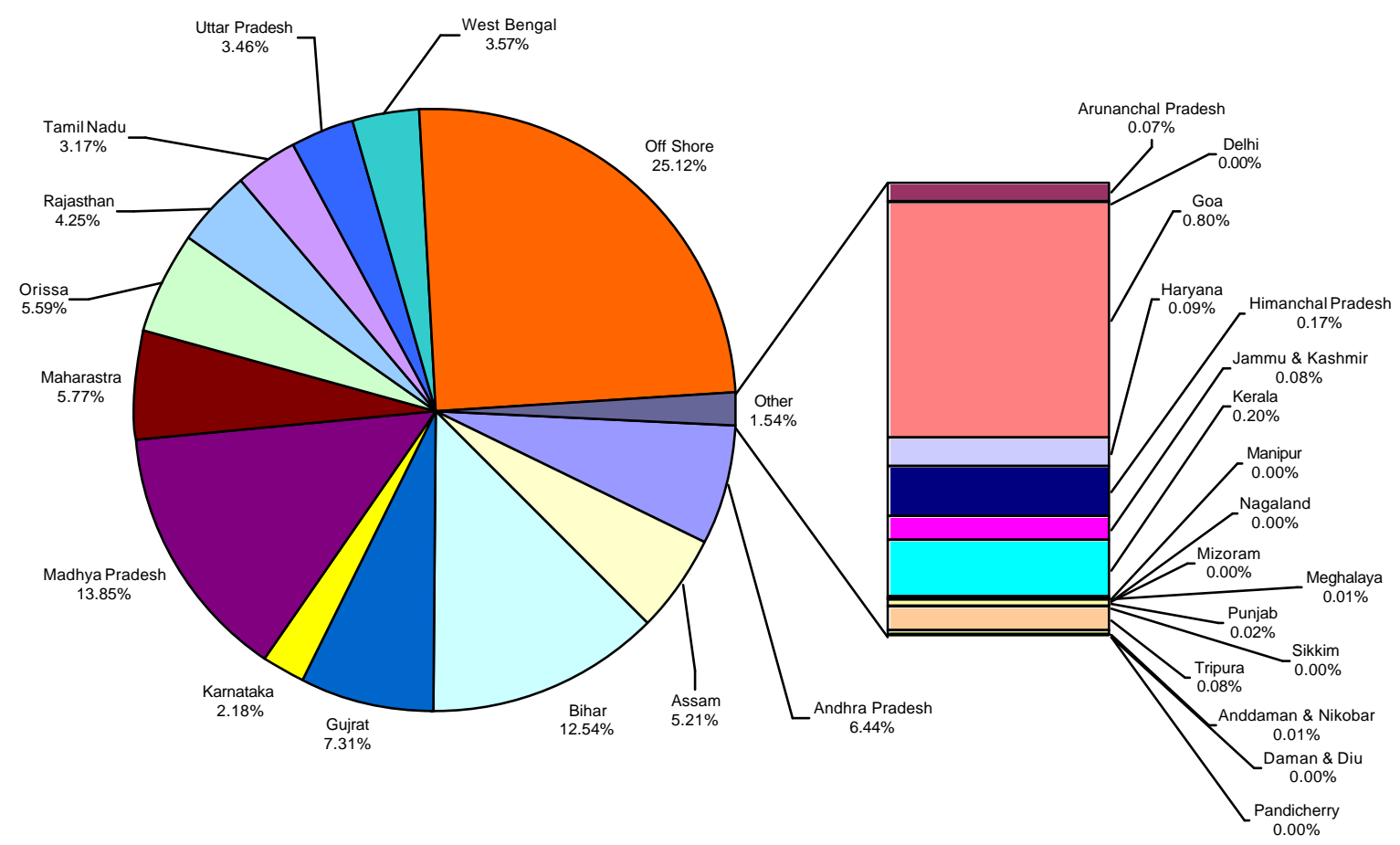

Source: Indian Bureau of Mines 1998-99 
Table 1

\section{Electricity production and consumption pattern in India and reference \\ countries}

Series Name

Electric power consumption (kwh per capita)

China

India

Australia

United States

Electricity production from coal sources (\% of total)

China

India

Australia

United States

Electricity production from hydroelectric sources (\% of total)

China

India

Australia

United States

Electricity production from natural gas sources (\% of total)

China

India

Australia

United States

Electricity production from nuclear sources (\% of total)

China

India

Australia

United States

Electricity production from oil sources (\% of total)

China

India

Australia

United States
$1990 \quad 1998$

$\begin{array}{rr}471 & 746 \\ 254 & 384 \\ 7572 & 8717 \\ 10558 & 11832\end{array}$

73

76

68

75

77

80

53

53

20

18

25

17

9

8

9

8

1

35

119

12

2 
Source: World Development Indicators CDROM2001

Table 2

\section{Energy consumption and per capita income of India and reference}

\section{countries}

\begin{tabular}{|c|c|c|c|c|c|c|c|}
\hline & & & & & & Growth & \\
\hline Series Name & Country Name & 1960 & 1980 & 1990 & 1998 & $60-80$ & $80-98$ \\
\hline Electric power & & & & & & & \\
\hline (kwh per capita & & & & & & & \\
\hline & Australia & 1708 & 5393 & 7572 & 8717 & 0.06 & 0.03 \\
\hline & China & & 264 & 471 & 746 & & 0.06 \\
\hline & United Kingdom & 2095 & 4160 & 4768 & 5327 & 0.03 & 0.01 \\
\hline & United States & 3808 & 8914 & 10558 & 11832 & 0.04 & 0.02 \\
\hline & India & & 130 & 254 & 384 & & 0.06 \\
\hline
\end{tabular}

GDP per capita

(constant 1995 US\$)

$\begin{array}{lrrrrrr}\text { Australia } & 9887 & 15950 & 18643 & 22821 & 0.02 & 0.02 \\ \text { China } & 112 & 168 & 349 & 725 & 0.02 & 0.08 \\ \text { United Kingdom } & 9496 & 14167 & 18081 & 20718 & 0.02 & 0.02 \\ \text { United States } & 13279 & 20981 & 26160 & 30135 & 0.02 & 0.02 \\ \text { India } & 183 & 227 & 324 & 430 & 0.01 & 0.04\end{array}$

Source: World Development Indicators CDROM2001 